\title{
DINAMIKA FRAKSI FOSFOR DAN SIFAT KIMIA TANAH SAWAH TERKAIT INDEKS PERTANAMAN PADI SAWAH DAN PRAKTIK PENGAIRAN
}

\section{Dynamics of Phosphorus Fractions and Chemical Properties of Paddy Soils as related to Paddy Rice Cropping Index and Irrigation Practices}

\author{
Untung Sudadi1)*, Laode Muhamad Asdiq Hamsin Ramadhan'), Budi Nugroho') \\ dan Arief Hartono1) \\ 1) Departemen Ilmu Tanah dan Sumberdaya Lahan, Fakultas Pertanian IPB, Jl. Meranti Kampus IPB Dramaga, \\ Bogor 16680 \\ 2) Alumni Program Studi Ilmu Tanah, Sekolah Pascasarjana IPB, Jl. Meranti Kampus IPB Dramaga, Bogor 16680
}

\begin{abstract}
Dynamics of $P$ fractions and other chemical properties of a paddy soil are related to paddy rice cropping index (CI) and soil water content at field condition $(S F W C)$. This explorative research was aimed at to evaluating the effects of different CIs represented by ameliorations and fertilizations applied by, and SFWC to represent irrigation practiced by farmers of the studied paddy soils on dynamics of $P$ fractions, other soil chemical properties, and paddy rice yield. Composite soil samples were taken from cultivated paddy fields with CI 100\%, 200\%, and 300\% at 7, 9, 11, and 13 weeks after the initial waterlogging. Soil $P$ were fractionated into soil $P_{\mathrm{H} 2 \mathrm{O}}, P_{\mathrm{NaHCO}-\text {-inorganic }(\mathrm{Pi})}, P_{\mathrm{NaHCO} \text {-organic }(\mathrm{Po})}, P_{\mathrm{NaOH}-\mathrm{P} i}, P_{\mathrm{NaOH}-\mathrm{Po}}$, and $P_{\mathrm{HCl}}$ fractions. At the four soil sampling times, SFWC at CI 100\% <200\% $\approx 300 \%$. At CI 100\%, soil Po fractions tended to decrease, whilst Pi fractions tended to increase with the increasing SFWC. Soil P dynamics in all CIs were predominantly determined by $C_{\text {org. }}$ Increase in $C_{\text {org }}$ decreased Pi fractions at CI 100\% and Po fractions at CI 200\% but increased Pi fractions at CI 300\%. Decreasing $P_{2} \mathrm{O}_{5}$ and increasing rice straw doses decreased soil Eh. Predominant factor affected rice paddy yield was SFWC.
\end{abstract}

Keywords: P fertilizer, rice straw, soil field water-content, soil P fractions

\section{ABSTRAK}

Dinamika fraksi-fraksi P dan sifat kimia lainnya pada tanah sawah terkait dengan indeks pertanaman padi sawah (IP) dan kadar air tanah pada kondisi lapang (KAL). Penelitian eksploratif ini bertujuan mengevaluasi pengaruh IP berbeda yang direpresentasikan oleh dosis ameliorasi dan pemupukan serta KAL sebagai representasi praktik pengairan yang diaplikasikan oleh petani pada tanah sawah penelitian terhadap dinamika fraksi P, sifat kimia tanah lainnya dan produksi padi sawah. Contoh tanah komposit diambil pada lahan sawah yang sedang dibudidayakan petani dengan IP 100\%, 200\% dan 300\% pada periode 7 , 9, 11 dan 13 minggu setelah penggenangan awal. Fraksionasi $\mathrm{P}$ dilakukan untuk memperoleh fraksi $\mathrm{P}_{\mathrm{H} 2 \mathrm{O}}, \mathrm{P}_{\mathrm{NaHCO} \text {-inorganik }(\mathrm{Pi})}$, $\mathrm{P}_{\mathrm{NaHCO} \text {-organik (Po), }} \mathrm{P}_{\mathrm{NaOH}-\mathrm{Pi}}, \mathrm{P}_{\mathrm{NaOH}-\mathrm{Po}}$ dan $\mathrm{P}_{\mathrm{HCl}}$ tanah. Nilai KAL pada keempat waktu pengambilan contoh tanah pada IP $100 \%<$ IP $200 \% \approx$ IP $300 \%$. Sifat-sifat kimia dan fraksi-fraksi Po pada IP 100\% cenderung menurun, sedangkan fraksi-fraksi Pi cenderung meningkat dengan peningkatan KAL. Dinamika fraksi-fraksi $\mathrm{P}$ tanah pada ketiga IP terutama ditentukan oleh $\mathrm{C}_{\text {org. }}$. Peningkatan $\mathrm{C}_{\text {org }}$ tanah menurunkan kadar Pi pada IP 100\% dan Po pada IP 200\%, tetapi meningkatkan Pi pada IP $300 \%$. Penurunan dosis $\mathrm{P}_{2} \mathrm{O}_{5}$ dan peningkatan dosis jerami menurunkan Eh tanah. Faktor yang paling berpengaruh terhadap produksi padi sawah adalah KAL.

Kata kunci : Pupuk P, jerami padi, kadar air lapang tanah, fraksi P tanah

\section{PENDAHULUAN}

Fosfor (P) tanah dijumpai dalam berbagai fraksi kimia (Tiessen dan Moir, 2008). Pada tanah sawah, kadar fraksi-fraksi $\mathrm{P}$, yang merupakan salah satu faktor penentu produktivitas tanah sawah, antara lain dipengaruhi oleh indeks pertanaman dan kondisi pengairan. Indeks Pertanaman padi sawah (IP) menunjukkan berapa kali dalam setahun lahan digunakan untuk budidaya padi sawah. Pada tanah sawah, selain kondisi pengairan, pengaruh IP terhadap sifat-sifat kimia tanah juga terkait dengan dosis ameliorasi dan pemupukan. Peningkatan IP, dalam praktiknya, tidak selalu selaras dengan peningkatan dosis amelioran atau pupuk per tahun yang diaplikasikan oleh petani. Dosis per musim tanam pada IP 100\% dapat lebih tinggi dari pada IP 300\%. Peningkatan rentang waktu sejak penggenangan awal juga tidak selalu selaras dengan peningkatan kadar air tanah pada kondisi lapang (KAL). Faktanya lahan sawah dapat dijumpai dalam berbagai kondisi KAL selama masa budidaya padi sawah, tergantung praktik pengelolaan air yang dilakukan petani. Dosis amelioran dan pupuk serta KAL mempengaruhi reaksi reduksi-oksidasi (redoks) tanah sehingga sangat menentukan dinamika sifat-sifat elektrokimia dan kimia tanah sawah.

Fosfor tanah dijumpai dalam tiga fraksi, yaitu: (1)

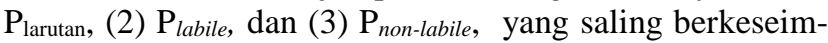
bangan. Fraksi ketiga lebih rendah ketersediaannya bagi tanaman daripada fraksi kedua dan fraksi kedua lebih rendah daripada fraksi pertama. Tiessen dan Moir (2008) 
membagi $\mathrm{P}$ tanah ke dalam 5 fraksi, yaitu: (1) $\mathrm{P}_{\text {Resin-Pi }}$ (Pinorganik), fraksi yang sangat tersedia bagi tanaman; (2) $\mathrm{P}_{\mathrm{NaHCO}-\mathrm{Pi}}$ dan -Po (Porganik), fraksi yang berkorelasi kuat dengan serapan tanaman dan mikrob serta yang tererap di permukaan mineral klei atau terpresipitasi sebagai Ca-P dan Mg-P; (3) $\mathrm{P}_{\mathrm{NaOH}-\mathrm{Pi}}$ dan -Po, fraksi yang terjerap lebih kuat secara kemisorpsi oleh Al- dan Fe-hidroksida; (4) $\mathrm{P}_{\mathrm{HCl}}$, fraksi Ca-P yang berkelarutan rendah, serta (5) $\mathrm{P}_{\text {residual, }}$, fraksi Pi- dan Po-terselubung atau occluded-P yang sangat sukar larut.

Potensial redoks (Eh) adalah sifat kimia tanah yang pertama kali berubah akibat pengairan (Ethan, 2015; Fan et al., 2008). Berkurangnya $\mathrm{O}_{2}$ dalam pori tanah akibat terdesak air menjadikan tanah sawah lebih reduktif atau menurun Eh-nya. Selanjutnya, pengairan menyebabkan konvergensi $\mathrm{pH}$, yaitu perubahan $\mathrm{pH}$ tanah menuju netral. Pada tanah masam yang banyak mengandung Fe, kondisi lebih reduktif akibat peningkatan KAL menyebabkan kenaikan $\mathrm{pH}$ yang dipengaruhi oleh reaksi keseimbangan $\mathrm{Fe}(\mathrm{OH})_{3} \rightarrow \mathrm{Fe}(\mathrm{OH})_{2}-\mathrm{H}_{2} \mathrm{O}$. Kondisi lebih reduktif akibat pengairan pada tanah alkalin menyebabkan penurunan $\mathrm{pH}$ yang dipengaruhi oleh reaksi keseimbangan $\mathrm{CaCO}_{3} \rightarrow \mathrm{CO}_{2}$ $\mathrm{H}_{2} \mathrm{O}$ (Ponnamperuma, 1978).

Peningkatan KAL akibat pengairan meningkatkan pelarutan ion-ion sehingga daya hantar listrik (DHL) larutan tanah meningkat dan menyebabkan sebagian fraksi $\mathrm{P}$ tanah yang semula tidak atau kurang tersedia bagi padi sawah menjadi lebih tersedia dan sebaliknya apabila KAL menurun (Chaudhari et al., 2013). Peningkatan kelarutan $\mathrm{P}$ tanah tersebut disebabkan oleh: (1) reduksi $\mathrm{FePO}_{4} \cdot 2 \mathrm{H}_{2} \mathrm{O}$ menjadi $\mathrm{Fe}_{3}\left(\mathrm{PO}_{4}\right)_{2} \cdot 8 \mathrm{H}_{2} \mathrm{O}$, (2) pelepasan kembali fosfat yang semula terjerap, (3) hidrolisis $\mathrm{FePO}_{4}$ dan $\mathrm{AlPO}_{4}$ pada tanah masam, serta (4) pelepasan occluded-P sehinga Pi terlepas ke larutan tanah (Gaol et al., 2013). Mekanisme pertama dan ketiga dapat dipelajari dengan mengevaluasi dinamika kadar $\mathrm{Fe}_{\text {terlarut }}$ selama periode pengamatan.

Selain mempengaruhi $\mathrm{C}_{\text {organik, ameliorasi bahan }}$ organik pada tanah sawah juga meningkatkan pengaruh pengairan terhadap penurunan Eh dan konvergensi $\mathrm{pH}$, karena $\mathrm{O}_{2}$ tersedia segera dipercepat penurunan kadarnya untuk proses dekomposisi bahan organik. Pemupukan $\mathrm{P}$ akan segera meningkatkan kadar fraksi $\mathrm{P}_{\text {tersedia }}$ (Faktor Intensitas), namun tidak semuanya akan diserap tanaman karena sebagiannya akan berubah menjadi fraksi-fraksi yang lebih tidak tersedia (Faktor Kapasitas) melalui mekanisme jerapan P yang bersifat spesifik (Cyio, 2008).

Penelitian eksploratif ini bertujuan mengevaluasi pengaruh KAL sebagai representasi pengaruh praktik pengairan, serta ameliorasi dan pemupukan yang diaplikasikan petani sebagai representasi pengaruh IP terhadap dinamika fraksi $\mathrm{P}$, sifat kimia tanah lainnya dan produksi padi sawah.

\section{BAHAN DAN METODE}

\section{Lokasi Lahan Sawah dan Pengambilan Contoh Tanah}

Contoh tanah diambil dari masing-masing 5 petakan lahan sawah milik petani di Kecamatan Dramaga, Kabupaten Bogor, Jawa Barat dengan IP 100\%, 200\% dan $300 \%$. Koordinat ketiga lahan sawah berturut-turut
6³2'51.8" LS, 106²3'45.9" BT; 6³3'03.2" LS, 106 44'10.4" BT; dan 6 633'02.4" LS, 10644'21.1" BT. Hasil analsis pendahuluan sifat kimia tanah sawah penelitian disajikan pada Tabel 1 .

Berdasarkan hasil wawancara dengan petani penggarap, lahan sawah dengan IP 100\%, 200\% dan 300\% tersebut berturut-turut diameliorasi dengan 900, 1320, dan 4200 kg.ha- ${ }^{-1}$ jerami; dan dipupuk P dengan dosis 120, 34.4, dan $36 \mathrm{~kg} \cdot \mathrm{ha}^{-1} \mathrm{P}_{2} \mathrm{O}_{5}$ per musim tanam, ditanami bibit padi sawah varietas Inpari 5, Inpari 5, dan Cisedane. Dosis amelioran dan pupuk ditentukan oleh petani (Tabel 2).

Contoh tanah komposit dari 5 titik acak diambil di setiap dari 5 petakan sawah dengan IP 100\%, 200\%, dan $300 \%$ pada $7,9,11$, dan 13 minggu setelah penggenangan awal di pertanaman pertama musim hujan 2015 (akhir Februari sampai awal Mei 2015), sehingga diperoleh 60 contoh tanah komposit sebagai bahan utama penelitian.

Contoh tanah diambil dengan cara menancapkan pipa paralon berdiameter 1.25 inchi sepanjang $60 \mathrm{~cm}$ ke dalam tanah sampai kedalaman $20 \mathrm{~cm}$. Pipa yang telah berisi tanah ditutup bagian bawahnya dengan telapak tangan dan diangkat secara perlahan. Contoh tanah dari setiap 5 titik acak dimasukkan ke dalam satu kantong plastik hitam, ditutup rapat, dicampurkan merata di dalam kantong plastik, diambil sekitar $200 \mathrm{~g}$, dipindahkan ke tabung kedap udara, dan disimpan dalam lemari pendingin di laboratorium pada suhu $4{ }^{\circ} \mathrm{C}$. Hal ini untuk menjaga agar contoh tanah semaksimal mungkin tetap berada dalam kondisi KAL. Sebelum pengambilan contoh tanah dilakukan pengamatan kondisi tanah terkait praktik pengairan.

\section{Analisis Tanah}

Analisis sifat kimia tanah dilakukan terhadap Eh dan $\mathrm{pH}\left(\mathrm{H}_{2} \mathrm{O} 1: 2.5\right.$, potensiometrik, Eh-pH meter), DHL (pasta tanah 1:1, EC meter), $\mathrm{C}_{\text {organik }}$ (Walkley \& Black), Fe terlarut (pasta tanah 1:1, AAS) dan fraksionasi P. Fraksionasi $\mathrm{P}$ dilakukan menurut metode Tiessen dan Moir (2008) yang dimodifikasi, yaitu fraksi Resin- $P$ diganti dengan $\mathrm{P}_{\mathrm{H} 2 \mathrm{O}}$. Dalam penelitian ini, kadar fraksi $P_{\text {residual }}$ tidak ditetapkan. Setelah fraksi $\mathrm{P}_{\mathrm{H} 2 \mathrm{O}}$, selanjutnya secara sekuensial dilakukan penetapan fraksi $\mathrm{P}_{\mathrm{NaHCO}-\mathrm{Pi}}$ dan $\mathrm{P}_{\text {total }}$ serta perhitungan $\mathrm{P}_{\mathrm{NaHCO} 3-\mathrm{Po}}, \mathrm{P}_{\mathrm{NaOH}-\mathrm{Pi}}$ dan $\mathrm{P}_{\text {total }}$ serta perhitungan $\mathrm{P}_{\mathrm{NaOH}-\mathrm{Po}}$ dan $\mathrm{P}_{\mathrm{HCl}-\mathrm{Pi}}$.

\section{Analisis Data}

Hasil penelitian disajikan dalam bentuk grafik hubungan antara sifat-sifat kimia dan kadar fraksi-fraksi $\mathrm{P}$ tanah sebagai ordinat dengan KAL pada masa 7-13 minggu setelah penggenangan awal yang diurutkan dari nilai KAL terendah ke tinggi sebagai absis pada kondisi IP 100\%, $200 \%$, dan 300\%. Analisis data juga dilakukan untuk menentukan persamaan regresi linier sederhana dan berganda menggunakan metode backward stepwise serta

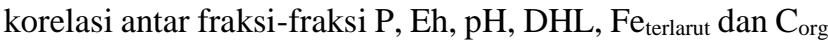
tanah, dosis jerami, dosis pupuk $\mathrm{P}$, KAL dan produksi GKP padi sawah menggunakan software MS Excell dan SPSS. 
Tabel 1. Hasil analisis pendahuluan sifat kimia tanah sawah penelitian sebelum aplikasi amelioran dan pupuk pada awal minggu kedua setelah penggenangan awal

\begin{tabular}{|c|c|c|c|c|c|c|c|c|}
\hline \multirow{2}{*}{$\begin{array}{c}\text { IP } \\
\text { Padi } \\
\text { sawah } \\
(\%) \\
\end{array}$} & \multirow{2}{*}{$\begin{array}{c}\mathrm{H}_{2} \mathrm{O} 1: 1 \\
\begin{array}{c}\mathrm{Eh} \\
(\mathrm{mV})\end{array}\end{array}$} & \multirow{2}{*}{$\begin{array}{c}\mathrm{H}_{2} \mathrm{O} 1: 2.5 \\
\mathrm{pH}\end{array}$} & \multirow{2}{*}{$\begin{array}{c}\mathrm{H}_{2} \mathrm{O} 1: 1 \\
\text { DHL } \\
\left({\left.\mathrm{S} . \mathrm{cm}^{-1}\right)}^{-1}\right.\end{array}$} & \multirow{2}{*}{$\begin{array}{c}\text { Walkley } \\
\& \text { Black } \\
\begin{array}{c}\text { Corganik } \\
(\%)\end{array}\end{array}$} & \multirow{2}{*}{$\begin{array}{c}\text { Kjeldahl } \\
\begin{array}{c}\mathrm{N}_{\text {total }} \\
(\%)\end{array}\end{array}$} & \multirow{2}{*}{$\begin{array}{c}\mathrm{HCl} 25 \% \\
\begin{array}{c}\mathrm{P}_{\text {total }} \\
(\mathrm{ppm})\end{array}\end{array}$} & \multicolumn{2}{|c|}{$N$ NH4OAc pH 7.0} \\
\hline & & & & & & & $\begin{array}{c}\mathrm{K}_{\text {dapat ditukar }} \\
\left(\mathrm{cmol}_{\mathrm{c}} \cdot \mathrm{kg}^{-1}\right)\end{array}$ & $\begin{array}{c}\text { KTK } \\
\left(\mathrm{cmol}_{\left.\mathrm{c} . \mathrm{kg}^{-1}\right)}\right)\end{array}$ \\
\hline 100 & 211 & 5.39 & 65.24 & 1.80 & 0.08 & 350 & 0.23 & 38.17 \\
\hline 200 & 207 & 5.22 & 114.28 & 2.04 & 0.08 & 415 & 0.08 & 38.64 \\
\hline 300 & 177 & 5.30 & 126.36 & 2.38 & 0.09 & 417 & 0.12 & 32.77 \\
\hline
\end{tabular}

Tabel 2. Dosis ameliorasi dan pemupukan yang diaplikasikan petani pada tanah sawah penelitian

\begin{tabular}{|c|c|c|c|c|c|c|c|c|c|c|}
\hline \multirow{2}{*}{$\begin{array}{c}\text { IP } \\
\text { Padi } \\
\text { sawah } \\
(\%) \\
\end{array}$} & \multirow{2}{*}{ Pola Tanam } & \multicolumn{8}{|c|}{$\begin{array}{c}\text { Dosis amelioran dan pupuk } \\
\left(\mathrm{kg} \cdot \mathrm{ha}^{-1}\right) \text { per musim tanam padi sawah }\end{array}$} & \multirow{2}{*}{$\begin{array}{l}\text { Produksi GKF } \\
\text { (ton.ha }^{-1} \text { ) per } \\
\text { musim tanam } \\
\text { padi sawah }\end{array}$} \\
\hline & & Urea & TSP & $\mathrm{KCl}$ & NPK & Jerami & $\mathrm{N}$ & $\mathrm{P}_{2} \mathrm{O}_{5}$ & $\mathrm{~K}_{2} \mathrm{O}$ & \\
\hline 100 & Kacang Tanah-Bengkoang-Padi Sawah & 125 & 125 & 0 & 500 & 900 & 133 & 133 & 75 & 3 \\
\hline 200 & Bera-Padi Sawah-Padi Sawah & 77 & 77 & 154 & 0 & 1320 & 35.4 & 35.4 & 46.2 & 4.4 \\
\hline 300 & Padi Sawah-Padi Sawah-Padi Sawah & 200 & 0 & 0 & 240 & 4200 & 128 & 36 & 36 & 7.2 \\
\hline
\end{tabular}

\section{HASIL DAN PEMBAHASAN}

\section{Dinamika Fraksi Fosfor dan Sifat Kimia Tanah}

Pada periode 7-13 minggu setelah penggenangan awal, KAL tanah sawah penelitian dengan IP $100 \%, 200 \%$ dan $300 \%$ berada pada kisaran $42-51 \%$, 81-83\% dan $82-$ $100 \%$ (Gambar 1). Peningkatan KAL menyebabkan penurunan Eh dan konvergensi $\mathrm{pH}$ tanah. Hal ini sesuai dengan hasil penelitian Chong et al. (2009). Eh semakin turun dengan meningkatnya KAL dan IP (Gambar 1). Hal ini berkaitan dengan peningkatan dosis jerami dari $900 \mathrm{~kg} \cdot \mathrm{ha}^{-1}$ pada IP $100 \%$ ke 1320 dan 4,200 kg.ha- ${ }^{-1}$ pada IP $200 \%$ dan $300 \%$. Semakin tinggi dosis jerami semakin tinggi dan cepat laju konsumsi oksigen untuk proses dekomposisinya, sehingga semakin menurunkan Eh (Duane et al., 2012).

Nilai $\mathrm{pH}$ tanah pada IP $100 \%$ sedikit menurun, namun pada IP $200 \%$ dan $300 \%$ terjadi tren peningkatan $\mathrm{pH}$ dengan meningkatnya KAL atau menurunnya Eh. Penurunan Eh menyebabkan reduksi $\mathrm{Fe}(\mathrm{OH})_{3}$ menjadi $\mathrm{Fe}(\mathrm{OH})_{2}$ dan melepaskan $\mathrm{OH}^{-}$sehingga meningkatkan $\mathrm{pH}$ tanah menurut reaksi: $\mathrm{Fe}(\mathrm{OH})_{3}+\mathrm{e}^{-} \rightarrow \mathrm{Fe}(\mathrm{OH})_{2}+\mathrm{OH}^{-}$.

Peningkatan KAL pada tanah sawah umumnya meningkatkan nilai DHL. Hal tersebut pada penelitian ini tidak terjadi pada IP $100 \%$ dan $200 \%$, namun pada IP $300 \%$ DHL cenderung meningkat dengan meningkatnya KAL (Gambar 1). Hal ini diduga berkaitan dengan amelio-rasi jerami hingga $4200 \mathrm{~kg} \cdot \mathrm{ha}^{-1}$ per musim tanam padi sawah. Menurut Iranpour et al. (2014), nilai DHL tanah sawah akan meningkat seiring dengan peningkatan dosis ameliorasi bahan organik dan dekomposisinya yang melepaskan ionion hara ke larutan tanah, diantaranya $\mathrm{NH}_{4}{ }^{+}$, sebagai hasil proses amonifikasi bahan organik. Pembentukan $\mathrm{NH}_{4}{ }^{+}$lebih cepat terjadi pada tanah dengan kadar $\mathrm{N}$ dan bahan organik tinggi (Nayak et al., 2009; Pampolino et al., 2008) seperti yang terjadi pada tanah penelitian dengan IP 300\% yang mengandung $2.38 \% \mathrm{C}_{\text {organik }}$ dan $0.09 \% \mathrm{~N}_{\text {total }}$ (Tabel 3).
Kadar $\mathrm{Fe}_{\text {terlarut }}$ pada IP $100 \%$ cenderung menurun selama periode 7-13 minggu setelah penggenangan awal dan sebaliknya pada IP 200\% dan 300\% (Gambar 1). Budidaya padi sawah yang hanya sekali setahun pada IP $100 \%$ menyebabkan tanah berada pada kondisi oksidatif yang berlangsung lebih lama, yaitu pada periode pertanaman kacang tanah dan bengkoang, sehingga dekomposisi bahan organik berlangsung lebih intensif, menurunkan nisbah $\mathrm{C} / \mathrm{N}$ dan menghasilkan asam humat yang dapat membentuk kompleks dengan dan menurunkan

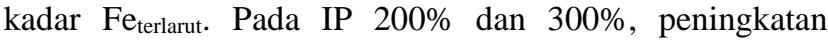
$\mathrm{Fe}_{\text {terlarut }}$ berkaitan dengan proses dekomposisi bahan organik pada kondisi lebih anaerobik yang menyebabkan reduksi $\mathrm{Fe}^{3+}$ menjadi $\mathrm{Fe}^{2+}$ menurut reaksi: $\mathrm{Fe}_{2} \mathrm{O}_{3}+1 / 2 \mathrm{CH}_{2} \mathrm{O}+4 \mathrm{H}^{+}$ $\rightarrow 2 \mathrm{Fe}^{2+}+5 / 2 \mathrm{H}_{2} \mathrm{O}+1 / 2 \mathrm{CO}_{2}$ (Sahrawat et al., 2012).

Pemupukan $120 \mathrm{~kg} \cdot \mathrm{ha}^{-1} \mathrm{P}_{2} \mathrm{O}_{5}$ per musim tanam padi sawah (Tabel 2) menyebabkan fraksi-fraksi $P$ tanah pada IP $100 \%$ cenderung meningkat selama periode pengamatan dan memiliki kadar tertinggi (Gambar 1). Tingginya kadar $P$ di larutan tanah akan menyebabkan peningkatan penjerapan P (Idris dan Ahmed, 2012), sehingga meningkatkan kadar fraksi $\mathrm{P}$ padatan yang dalam hal ini adalah fraksi $\mathrm{P}_{\mathrm{NaOH}-\mathrm{Pi}}$ dan $\mathrm{P}_{\mathrm{HCl}-\mathrm{Pi} \text {. Hartono et al. (2006) }}$ mendapatkan peningkatan fraksi $\mathrm{P}_{\mathrm{NaOH}-\mathrm{Pi}}$ pada tanah yang ditambahkan 300 mg. $\mathrm{kg}^{-1} \mathrm{P}$ setelah diinkubasi 90 jam. Pada IP $200 \%$ dan $300 \%$, penggenangan menyebabkan pelarutan fraksi $\mathrm{P}_{\mathrm{HCl}-\mathrm{Pi}}$ menjadi $\mathrm{P}_{\mathrm{NaOH}-\mathrm{Pi}}$ yang ditandai oleh menurunnya kadar fraksi $\mathrm{P}_{\mathrm{HCl}-\mathrm{Pi}}$ dan meningkatnya kadar $\mathrm{P}_{\mathrm{NaOH}-\mathrm{Pi}}($ Gambar 1).

Secara umum, dinamika fraksi-fraksi $\mathrm{P}$ tanah sawah pada ketiga IP yang diteliti disebabkan oleh proses keseimbangan antara Faktor Intensitas (IF) dengan Faktor Kapasitas (CF). CF menunjukkan kapasitas fase padatan tanah untuk melepaskan ion hara yang berkurang kadarnya dalam larutan tanah (IF) akibat serapan oleh tanaman, pencucian atau volatilisasi dan sebaliknya. Perubahan fraksi $\mathrm{P}$ juga dipengaruhi oleh dinamika sifat kimia pada ketiga IP selama periode pengamatan. 

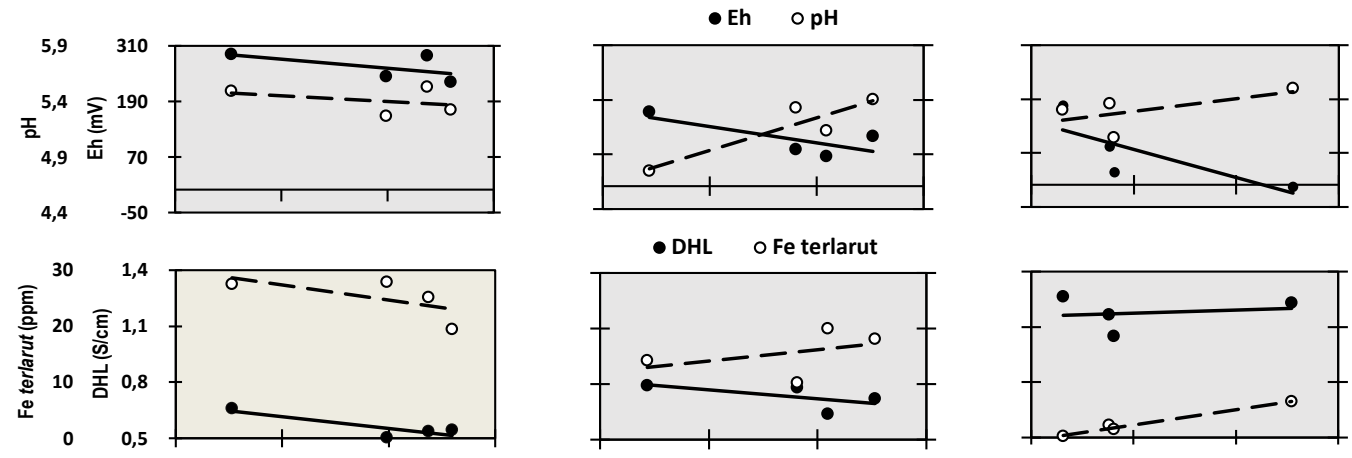

- DHL OFe terlarut
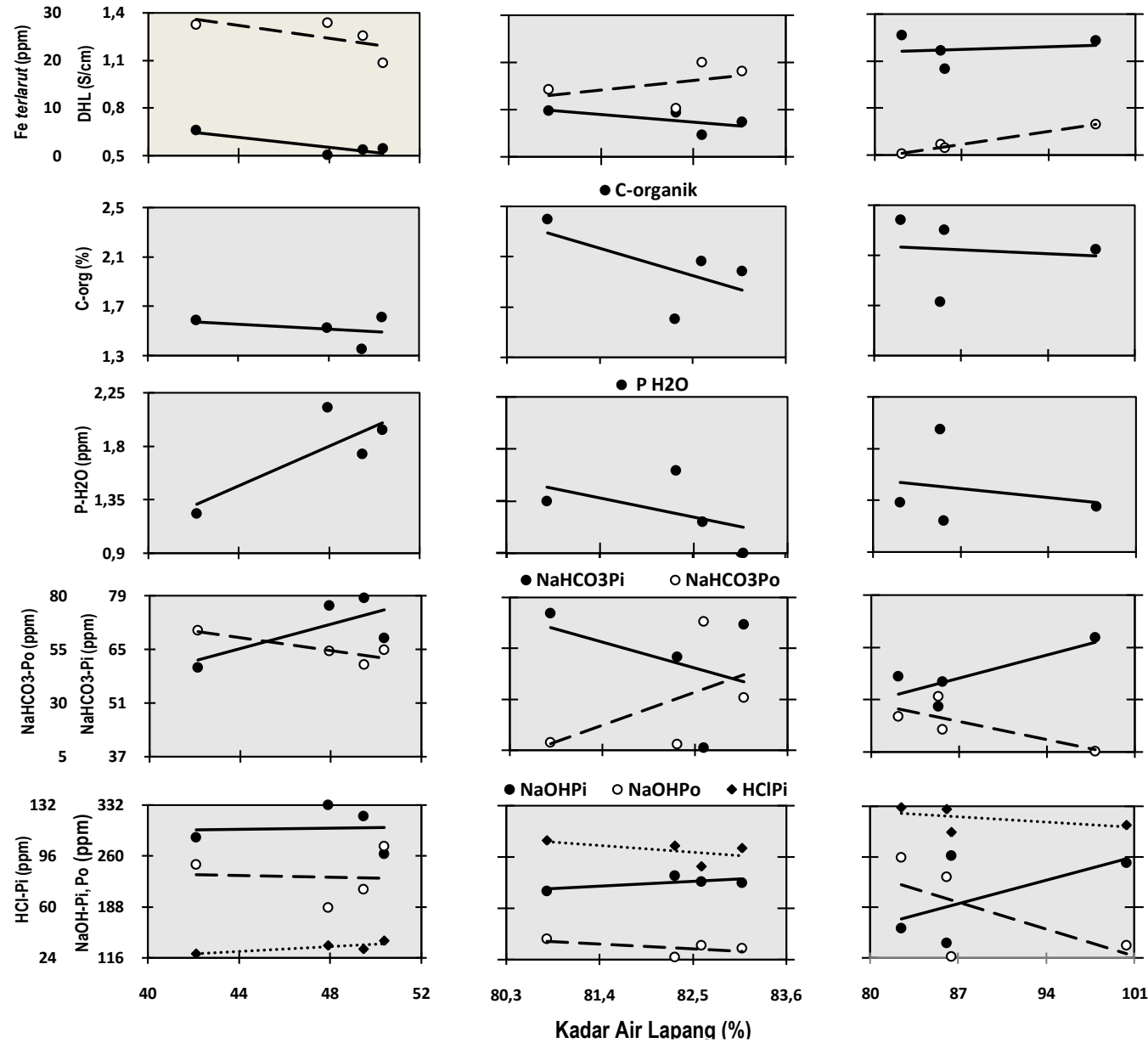

\begin{tabular}{c|c|c|c|c|c|c|c|c|c|c|c|c}
\multicolumn{4}{|c|}{ IP Padi Sawah } & \multicolumn{4}{|c|}{$\mathbf{1 0 0 \%}$} & \multicolumn{4}{c}{$\mathbf{2 0 0 \%}$} \\
\hline Kondisi Lahan* & $\mathbf{t t}$ & $\mathbf{t t}$ & $\mathbf{m}$ & $\mathbf{m}$ & $\mathbf{t t}$ & $\mathbf{t t}$ & $\mathbf{m}$ & $\mathbf{m}$ & $\mathbf{t t}$ & $\mathbf{m}$ & $\mathbf{m}$ & $\mathbf{t g}$ \\
\hline Masa Pengairan (Minggu**) & 13 & $\mathbf{9}$ & $\mathbf{1 1}$ & $\mathbf{7}$ & $\mathbf{7}$ & $\mathbf{9}$ & $\mathbf{1 3}$ & $\mathbf{1 1}$ & $\mathbf{1 1}$ & $\mathbf{1 3}$ & $\mathbf{9}$ & $\mathbf{7}$ \\
\hline
\end{tabular}

Dosis Amelioran dan Pupuk

(kg.ha-1) per Musim

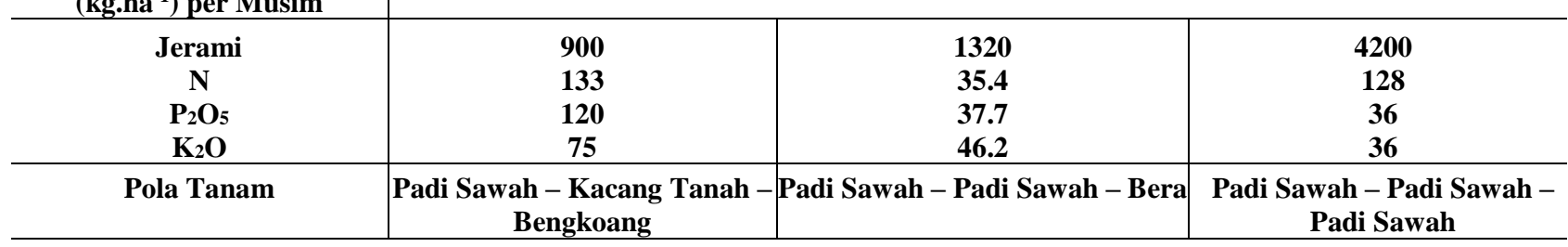

* $\mathrm{tt}$ : tidak tergenang; $\mathrm{m}=$ macak-macak; tg: tergenang

** setelah penggenangan awal di pertanaman pertama musim hujan 2015, yaitu pada akhir Februari sampai awal Mei 2015

Gambar 1. Hubungan kadar fraksi-fraksi P dan sifat-sifat kimia tanah lainnya dengan kadar air kondisi lapang pada tanah sawah dengan IP $100 \%, 200 \%$ dan $300 \%$ selama masa pengairan 7 sampai 13 minggu setelah penggenangan awal.

\section{Hubungan Fraksi P dengan Sifat Kimia Tanah}

Berdasarkan hasil analisis regresi linier berganda, dari 5 sifat kimia tanah yang dievaluasi, yang berpengaruh paling nyata terhadap dinamika fraksi P pada IP $100 \%$ hanya kadar $\mathrm{C}_{\text {org }}$ terhadap fraksi-fraksi Pi (Tabel 3, persamaan $\left.(2), r=-0.496 ; p=0.036^{*}\right)$. Semakin rendah kadar $\mathrm{C}_{\text {org }}$ maka semakin tinggi kadar fraksi-fraksi Pi. Menurunnya kadar $\mathrm{C}_{\text {org }}$ menunjukkan terjadinya dekomposisi bahan organik yang juga melepaskan ion hara dalam bentuk organik termasuk Po. Peningkatan kadar Po mendorong terjadinya mineralisasi Po menjadi Pi sehingga meningkatkan kadar Pi. 
Secara umum, dalam tanah terjadi mineralisasi dan imobilisasi P secara berkesinambungan (Gupta at al., 2007) menurut reaksi:

$$
\mathrm{P}_{\text {organik }} \underset{\text { Imobilisasi }}{\stackrel{\text { Mineralisasi }}{\longrightarrow}} \mathrm{P}_{\text {inorganik }}\left(\mathrm{H}_{2} \mathrm{PO}_{4}^{-} \text {atau } \mathrm{HPO}_{4}{ }^{2-}\right)
$$

Sifat kimia tanah yang berpengaruh paling nyata terhadap dinamika fraksi P pada IP $200 \%$ adalah kadar $\mathrm{C}_{\text {org }}$ dan DHL secara simultan terhadap fraksi-fraksi Po (Tabel
3, persamaan $(8), \mathrm{R}^{2}=0.418 ; \mathrm{p}=0.010 *$ ). Persamaan ini menunjukkan bahwa setiap penurunan $0.01 \% \mathrm{C}_{\text {org }}$ dan peningkatan $0.01 \mathrm{~S} . \mathrm{cm}^{-1}$ DHL secara simultan akan diikuti oleh peningkatan $1.23+0.57=1.8 \mathrm{ppm}$ Po. Peningkatan fraksi-fraksi Po tersebut diduga berasal dari proses dekomposisi jerami dan imobilisasi Pi dari pupuk P.

Kadar $\mathrm{C}_{\text {org }}, \mathrm{Fe}_{\text {terlarut }}$ dan Eh secara simultan berpengaruh sangat nyata dan paling nyata terhadap dinamika fraksi- fraksi Pi pada IP 300\%.

Tabel 3. Persamaan regresi linier berganda hubungan antara fraksi $\mathrm{P}$ tanah (Y) dengan sifat-sifat kimia tanah (X) yang signifikan korelasinya pada tanah sawah dengan IP 100\%, 200\% dan 300\% pada periode 7, 9, 11, dan 13 minggu setelah penggenangan awal

\begin{tabular}{|c|c|c|c|c|c|c|c|}
\hline $\mathrm{Y}^{*}$ & $\mathrm{X}^{*}$ & r parsial & $\mathrm{p}$ & Persamaan* & $R^{2}$ atau $\mathrm{r}$ & $\mathrm{p}$ & $\mathrm{n}$ \\
\hline \multicolumn{8}{|l|}{ IP $100 \%$} \\
\hline \multirow{2}{*}{ 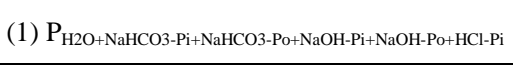 } & Eh & -0.212 & 0.413 & $Y_{(1)}=793.71-0.43 \mathrm{Eh}$ & \multirow{2}{*}{-0.209} & \multirow{2}{*}{0.406} & \multirow{2}{*}{$18^{* *}$} \\
\hline & $\mathrm{C}_{\text {org }}$ & -0.041 & 0.873 & $-12.84 \mathrm{C}_{\mathrm{org}}$ & & & \\
\hline (2) $\mathrm{P}_{\mathrm{H} 2 \mathrm{O}+\mathrm{NaHCO} 3-\mathrm{Pi}+\mathrm{NaOH}-\mathrm{Pi}+\mathrm{HCl}-\mathrm{Pi}}$ & $\mathrm{C}_{\text {org }}$ & & & $Y_{(2)}=601.46-128.48 C_{\text {org }}$ & -0.496 & 0.036 & $18^{* *}$ \\
\hline (3) $\mathrm{P}_{\mathrm{H} 2 \mathrm{O}+\mathrm{NaHCO} 3-\mathrm{Po}+\mathrm{NaOH}-\mathrm{Po}}$ & $\mathrm{C}_{\text {org }}$ & & & $\mathrm{Y}_{(3)}=90.52+125.18 \mathrm{C}_{\mathrm{org}}$ & 0.423 & 0.080 & $18 * *$ \\
\hline (4) $\mathrm{P}_{\mathrm{NaHCO} 3-\mathrm{Po}+\mathrm{NaOH}-\mathrm{Po}}$ & $\mathrm{C}_{\text {org }}$ & & & $\mathrm{Y}_{(4)}=87.12+126.22 \mathrm{C}_{\mathrm{org}}$ & 0.427 & 0.078 & $18^{* * *}$ \\
\hline \multicolumn{8}{|l|}{ IP $200 \%$} \\
\hline (5) $\mathrm{P}_{\mathrm{H} 2 \mathrm{O}+\mathrm{NaHCO} 3-\mathrm{Pi}+\mathrm{NaHCO} 3-\mathrm{Po}+\mathrm{NaOH}-\mathrm{Pi}+\mathrm{NaOH}-\mathrm{Po}+\mathrm{HCl}-\mathrm{Pi}}$ & DHL & & & $\mathrm{Y}_{(5)}=689.03-191.10 \mathrm{DHL}$ & 0.199 & 0.400 & 20 \\
\hline (6) $\mathrm{P}_{\mathrm{H} 2 \mathrm{O}+\mathrm{NaHCO} 3-\mathrm{Pi}+\mathrm{NaOH}-\mathrm{Pi}+\mathrm{HCl}-\mathrm{Pi}}$ & $\mathrm{pH}$ & & & $Y_{(6)}=-487.28+165.23 \mathrm{pH}$ & 0.219 & 0.354 & 20 \\
\hline (7) $\mathrm{P}_{\mathrm{H} 2 \mathrm{O}+\mathrm{NaHCO} 3-\mathrm{Po}+\mathrm{NaOH}-\mathrm{Po}}$ & $\begin{array}{l}\mathrm{C}_{\text {org }} \\
\text { DHL }\end{array}$ & $\begin{array}{c}0.562 \\
-0.451 \\
\end{array}$ & $\begin{array}{l}0.012 \\
0.053\end{array}$ & $\begin{array}{l}\mathrm{Y}_{(7)}=137.13+57.38 \mathrm{C}_{\text {org }} \\
-122.47 \mathrm{DHL}\end{array}$ & 0.417 & 0.010 & 20 \\
\hline (8) $\mathrm{P}_{\mathrm{NaHCO}-\mathrm{Po}+\mathrm{NaOH}-\mathrm{Po}}$ & $\begin{array}{c}\mathrm{C}_{\text {org }} \\
\mathrm{DHL}\end{array}$ & $\begin{array}{r}0.563 \\
-0.451 \\
\end{array}$ & $\begin{array}{l}0.012 \\
0.052\end{array}$ & $\begin{array}{l}Y_{(8)}=135.73+57.60 \mathrm{C}_{\text {org }} \\
-122.88 \mathrm{DHL}\end{array}$ & 0.418 & 0.010 & 20 \\
\hline \multicolumn{8}{|l|}{ IP $300 \%$} \\
\hline 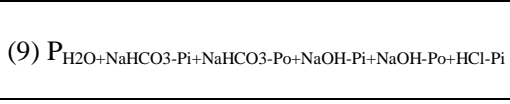 & $\begin{array}{c}\mathrm{pH} \\
\mathrm{C}_{\text {org }} \\
\mathrm{Fe}_{\text {terlarut }}\end{array}$ & $\begin{array}{c}0.605 \\
0.684 \\
-0.563 \\
\end{array}$ & $\begin{array}{l}0.008 \\
0.002 \\
0.015 \\
\end{array}$ & $\begin{array}{l}\mathrm{Y}_{(9)}=-1080.73+253.97 \mathrm{pH} \\
+165.60 \mathrm{C}_{\mathrm{org}}-8.50 \mathrm{Fe}_{\text {terlarut }}\end{array}$ & 0.621 & 0.001 & 20 \\
\hline (10) $\mathrm{P}_{\mathrm{H} 2 \mathrm{O}+\mathrm{NaHCO}-\mathrm{Pi}+\mathrm{NaOH}-\mathrm{Pi}+\mathrm{HCl}-\mathrm{Pi}}$ & $\begin{array}{c}\text { Eh } \\
\mathrm{C}_{\text {org }} \\
\mathrm{Fe}_{\text {terlarut }} \\
\end{array}$ & $\begin{array}{c}-0.772 \\
0.682 \\
-0.463 \\
\end{array}$ & $\begin{array}{l}0.000 \\
0.002 \\
0.053 \\
\end{array}$ & $\begin{array}{l}Y_{(10)}=188.90-0.69 \mathrm{Eh} \\
+119.63 \mathrm{C}_{\text {org }}-4.68 \mathrm{Fe}_{\text {terlarut }}\end{array}$ & 0.723 & 0.000 & 20 \\
\hline (11) $\mathrm{P}_{\mathrm{H} 2 \mathrm{O}+\mathrm{NaHCO} 3-\mathrm{Po}+\mathrm{NaOH}-\mathrm{Po}}$ & Eh & & & $\mathrm{Y}_{(11)}=170.31+0.49 \mathrm{Eh}$ & 0.363 & 0.039 & 20 \\
\hline (12) $\mathrm{P}_{\mathrm{NaHCO} 3-\mathrm{Po}+\mathrm{NaOH}-\mathrm{Po}}$ & Eh & & & $\mathrm{Y}_{(12)}=168.91-0.49 \mathrm{Eh}$ & 0.465 & 0.03 & 20 \\
\hline
\end{tabular}

* Kadar fraksi P dan Feterlarut dalam ppm; Corg \%; DHL S cm ${ }^{-1}$; ** 2 data outliers tidak digunakan

Persamaan (10) pada Tabel $3\left(\mathrm{R}^{2}=0.723 ; \mathrm{p}=\right.$ $0.00 * *)$ menunjukkan bahwa setiap penurunan $1 \mathrm{mV}$ Eh dan $0.01 \mathrm{ppm} \mathrm{Fe}_{\text {terlarut }}$ serta peningkatan $0.01 \% \mathrm{C}_{\text {org }}$ secara simultan akan meningkatkan kadar fraksi Pi sejumlah $0.69+1.19+0.05=1.93$ ppm. Peningkatan kadar Pi antara lain berasal dari ameliorasi jerami ( $\mathrm{C} / \mathrm{N}$ tinggi). Ameliorasi jerami meningkatkan kebutuhan oksigen untuk proses dekomposisinya dan menyebabkan kadar oksigen tanah lebih cepat berkurang sehingga proses reduksi lebih intensif dan semakin cepat menurunkan nilai Eh tanah.

\section{Hubungan Sifat Kimia dan Fraksi P dengan IP dan KAL}

Dosis $\mathrm{P}_{2} \mathrm{O}_{5}$ dan jerami yang merepresentasikan IP berpengaruh paling nyata terhadap Eh. Persamaan regresi (Tabel 4) menunjukkan bahwa penurunan $10 \mathrm{~kg} \cdot \mathrm{ha}^{-1}$ per musim dosis $\mathrm{P}_{2} \mathrm{O}_{5}$ akan meningkatkan $16 \mathrm{mV}$ Eh jika peubah dosis jerami tetap dan peningkatan $100 \mathrm{~kg} \mathrm{ha}^{-1}$ per musim dosis jerami akan menurunkan $1.0 \mathrm{mV}$ Eh jika peubah dosis $\mathrm{P}_{2} \mathrm{O}_{5}$ tetap. Meningkatnya Eh menunjukkan perubahan kondisi tanah yang menjadi semakin oksidatif.

Ketersediaan $\mathrm{P}$ pada kondisi yang lebih oksidatif akan berkurang karena difiksasi oleh $\mathrm{Fe}^{3+}$ dalam bentuk $\mathrm{FePO}_{4}$ yang sukar larut. Hal tersebut mengindikasikan bahwa penambahan dosis $\mathrm{P}_{2} \mathrm{O}_{5}$ pada sawah penelitian kurang efisien karena $\mathrm{P}$ dari pupuk $\mathrm{P}_{2} \mathrm{O}_{5}$ sebagian besar akan diubah menjadi bentuk $\mathrm{P}$ tidak tersedia yaitu $\mathrm{FePO}_{4}$ sebagai akibat dari peningkatan Eh.

Dosis $\mathrm{P}_{2} \mathrm{O}_{5}$ dan KAL berpengaruh paling nyata terhadap fraksi Po. Persamaan regresi (Tabel 4) menunjukkan bahwa peningkatan $10 \mathrm{~kg} \cdot \mathrm{ha}^{-1}$ per musim dosis $\mathrm{P}_{2} \mathrm{O}_{5}$ akan meningkatkan 26 ppm fraksi-fraksi Po jika peubah KAL tetap dan peningkatan $1 \% \mathrm{KAL}$ akan meningkatkan 3.6 ppm fraksi-fraksi Po jika peubah dosis $\mathrm{P}_{2} \mathrm{O}_{5}$ tetap.

Kadar Pi pada tanah sawah penelitian sudah cukup tinggi. Akibatnya, penambahan dosis pupuk P2O5 akan menstimulasi imobilisasi $\mathrm{P}$ oleh mikrob yang mengubah bentuk Pi menjadi Po. Setelah aplikasi pupuk fosfat yang bersifat mudah larut akan terjadi imobilisasi secara cepat terhadap Pi yang ditambahkan (Bünemann et al., 2012).

\section{Hubungan Produksi Padi Sawah dengan IP, KAL, Fraksi P dan Sifat Kimia Tanah}

Hasil analisis regresi linier berganda (Tabel 5) menunjukkan bahwa dari faktor-faktor produksi padi sawah yang dievaluasi, yaitu IP yang direpresentasikan oleh dosis $\mathrm{P}_{2} \mathrm{O}_{5}$ dan jerami, praktik pengairan yang direpresentasikan oleh KAL, serta dinamika fraksi-fraksi $\mathrm{P}$ dan sifat-sifat kimia tanah lainnya, yang paling mem-pengaruhi produksi padi sawah adalah KAL (Tabel 5, persamaan $(2) ; \mathrm{r}=0.785$; $\left.\mathrm{p}=0.00^{* *}\right)$.

Berdasarkan persamaan (2) (Tabel 5), produksi padi akan meningkat 0.07 ton.ha ${ }^{-1}$ apabila KAL meningkat $1 \%$. 
Peningkatan KAL menurunkan Eh. Pada Eh lebih rendah, ketersediaan $\mathrm{P}, \mathrm{K}, \mathrm{Fe}, \mathrm{Mn}$ dan Si yang merupakan hara esensial bagi padi sawah akan meningkat (Ponnamperuma,
1985) sehingga meningkatkan pertumbuhan dan produksi padi sawah.

Tabel 4. Persamaan regresi linier berganda hubungan antara fraksi $\mathrm{P}$ dan sifat-sifat kimia tanah (Y) dengan dosis jerami dan pupuk $\mathrm{P}$ serta KAL (X) yang signifikan korelasinya pada periode $7,9,11$, dan 13 minggu setelah penggenangan awal

\begin{tabular}{|c|c|c|c|c|c|c|c|}
\hline $\mathrm{Y}^{*}$ & $\mathrm{X}^{*}$ & $\mathrm{r}$ & $\mathrm{p}$ & Persamaan* & $R^{2}$ atau $\mathrm{r}$ & $\mathrm{p}$ & $\mathrm{n} * *$ \\
\hline (1) $\mathrm{Eh}$ & $\begin{array}{c}\mathrm{P}_{2} \mathrm{O}_{5} \\
\text { Jerami }\end{array}$ & $\begin{array}{r}0.699 \\
-0.331 \\
\end{array}$ & $\begin{array}{l}0.000 \\
0.077 \\
\end{array}$ & $\begin{array}{l}\mathrm{Eh}=-81.12+1.62 \mathrm{P}_{2} \mathrm{O}_{5} \\
-0.02 \text { Jerami }\end{array}$ & 0.660 & 0.000 & 58 \\
\hline (2) $\mathrm{C}_{\text {org }}$ & KAL & & & $\mathrm{C}_{\text {org }}=0.83+0.02 \mathrm{KAL}$ & 0.448 & 0.000 & 58 \\
\hline (3) Fe $_{\text {terlarut }}$ & $\begin{array}{c}\mathrm{P}_{2} \mathrm{O}_{5} \\
\text { Jerami }\end{array}$ & $\begin{array}{r}0.285 \\
-0.364 \\
\end{array}$ & $\begin{array}{l}0.007 \\
0.000 \\
\end{array}$ & $\begin{array}{l}\mathrm{Fe}^{2+}=19.87+0.07 \mathrm{P}_{2} \mathrm{O}_{5} \\
-0.01 \text { Jerami }\end{array}$ & 0.509 & 0.000 & 58 \\
\hline (4) DHL & $\begin{array}{c}\text { KAL } \\
\text { Jerami }\end{array}$ & $\begin{array}{l}0.225 \\
0.578 \\
\end{array}$ & $\begin{array}{l}0.023 \\
0.000 \\
\end{array}$ & $\begin{array}{l}\mathrm{DHL}=0.22+0.004 \mathrm{KAL} \\
+3.72 \mathrm{E}^{-5} \text { Jerami }\end{array}$ & 0.575 & 0.000 & 58 \\
\hline (5) $\mathrm{pH}$ & $\mathrm{P}_{2} \mathrm{O}_{5}$ & & & $\mathrm{pH}=5.26+0.001 \mathrm{P}_{2} \mathrm{O}_{5}$ & 0.264 & 0.045 & 58 \\
\hline (6) $\mathrm{P}_{\mathrm{H} 2 \mathrm{O}+\mathrm{NaHCO} 3-\mathrm{Po}+\mathrm{NaOH}-\mathrm{Po}}$ atau $\mathrm{Po}_{(1)}$ & $\begin{array}{l}\mathrm{P}_{2} \mathrm{O}_{5} \\
\mathrm{KAL}\end{array}$ & $\begin{array}{l}0.609 \\
0.435 \\
\end{array}$ & $\begin{array}{l}0.000 \\
0.000 \\
\end{array}$ & $\begin{array}{l}\mathrm{Po}_{(1)}=-260.00+2.58 \mathrm{P}_{2} \mathrm{O}_{5} \\
+4.12 \mathrm{KAL}\end{array}$ & 0.453 & 0.000 & 58 \\
\hline 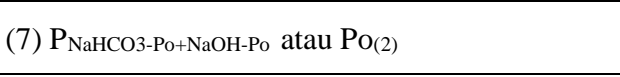 & $\begin{array}{l}\mathrm{P}_{2} \mathrm{O}_{5} \\
\mathrm{KAL}\end{array}$ & $\begin{array}{l}0.608 \\
0.434 \\
\end{array}$ & $\begin{array}{l}0.000 \\
0.000 \\
\end{array}$ & $\begin{array}{l}\mathrm{Po}_{(2)}=-208.93+2.62 \mathrm{P}_{2} \mathrm{O}_{5} \\
+3.61 \mathrm{KAL}\end{array}$ & 0.456 & 0.000 & 58 \\
\hline $\begin{array}{l}\text { (8) } \mathrm{P}_{\mathrm{H} 2 \mathrm{O}+\mathrm{NaHCO}}-\mathrm{Pi}+\mathrm{NaHCO} 3-\mathrm{Po}+\mathrm{NaOH}-\mathrm{Pi}+\mathrm{NaOH}-\mathrm{Po}+\mathrm{HCl}-\mathrm{Pi} \\
\text { atau } \mathrm{P}_{\text {total }}\end{array}$ & $\begin{array}{l}\mathrm{P}_{2} \mathrm{O}_{5} \\
\mathrm{KAL}\end{array}$ & $\begin{array}{l}0.487 \\
0.321\end{array}$ & $\begin{array}{l}0.000 \\
0.015\end{array}$ & $\begin{array}{l}\mathrm{P}_{\text {total }}=134.39+3.00 \mathrm{P}_{2} \mathrm{O}_{5} \\
+3.97 \mathrm{KAL}\end{array}$ & 0.319 & 0.000 & 58 \\
\hline
\end{tabular}

* Fraksi P dan $\mathrm{Fe}_{\text {terlarut }}$ dalam ppm; Corg \%; DHL S cm${ }^{-1}$; dosis $\mathrm{P}_{2} \mathrm{O}_{5}$ dan jerami kg ha ${ }^{-1}$ musim ${ }^{-1}$; KAL \%; ** 2 data outliers tidak digunakan

Tabel 5. Persamaan regresi linier berganda hubungan antara produksi (Y) dengan dosis jerami dan pupuk $\mathrm{P}, \mathrm{KAL}$, fraksi $\mathrm{P}$ serta sifat-sifat kimia tanah (X) yang signifikan korelasinya pada periode 7, 9, 11, dan 13 minggu setelah penggenangan awal

\begin{tabular}{|c|c|c|c|c|c|c|c|}
\hline $\mathrm{Y}^{*}$ & $\mathrm{X}^{*}$ & $\mathrm{r}$ & $\mathrm{p}$ & Persamaan* & $R^{2}$ atau r & $\mathrm{p}$ & $\mathrm{n} * *$ \\
\hline (1) Produksi & $\mathrm{P}_{2} \mathrm{O}_{5}$ & & & Produksi $=6.66-0.03 \mathrm{P}_{2} \mathrm{O}_{5}$ & -0.685 & 0.000 & 58 \\
\hline (2) Produksi & KAL & & & Produksi $=-0.47+0.07 \mathrm{KAL}$ & 0.785 & 0.000 & 58 \\
\hline (3) Produksi & $\begin{array}{c}\text { Eh } \\
\text { Fe terlarut } \\
\text { DHL }\end{array}$ & $\begin{array}{c}-0.518 \\
-0.425 \\
0.529 \\
\end{array}$ & $\begin{array}{l}0.000 \\
0.001 \\
0.000 \\
\end{array}$ & $\begin{array}{l}\text { Produksi }=4.78-0.01 \mathrm{Eh} \\
-0.04 \mathrm{Fe}_{\text {terlarut }}+1.97 \mathrm{DHL}\end{array}$ & 0.764 & 0.000 & 58 \\
\hline (4) Produksi & $\mathrm{P}_{2} \mathrm{O}+\mathrm{NaHCO} 3-\mathrm{Po}+\mathrm{NaOH}-\mathrm{Po}$ & & & Produksi $=6.18-0.01 \mathrm{PH} 2 \mathrm{O}+\mathrm{NaHCO} 3-\mathrm{Po}+\mathrm{NaOH}-\mathrm{Po}$ & -0.269 & 0.041 & 58 \\
\hline
\end{tabular}

* Produksi dalam ton $\mathrm{ha}^{-1}$; fraksi $\mathrm{P}$ dan Feterlarut ppm; DHL S cm${ }^{-1}$; dosis $\mathrm{P}_{2} \mathrm{O}_{5}$ dan jerami kg ha ${ }^{-1} \mathrm{musim}^{-1}$; KAL \%; ** 2 data outliers tidak digunakan.

\section{SIMPULAN}

Nilai Eh, pH, dan DHL, serta kadar Feterlarut, Corg, $\mathrm{P}_{\text {NaHCO3-Po dan }} \mathrm{P}_{\text {NaOH-Po pada }}$ IP $100 \%$ cenderung menurun, sedangkan $\mathrm{P}_{\mathrm{H} 2 \mathrm{O}}, \mathrm{P}_{\mathrm{NaHCO}-\mathrm{Pi}}, \mathrm{P}_{\mathrm{NaOH}-\mathrm{Pi}}$ dan $\mathrm{P}_{\mathrm{HCl}-\mathrm{P}}$ cenderung meningkat dengan peningkatan KAL. Kadar $\mathrm{P}_{\mathrm{NaOH}-\mathrm{Pi}}$ dan $\mathrm{P}_{\mathrm{NaOH}-\mathrm{Po}}$, fraksi $\mathrm{P}$ dan sifat-sifat kimia tanah lainnya kecuali DHL, pada IP $200 \%$ dan $300 \%$, menunjukkan tren perubahan yang selaras, karena KAL pada kedua IP tersebut relatif sama. Dinamika fraksi-fraksi $\mathrm{P}$ pada ketiga IP terutama ditentukan oleh $\mathrm{C}$-org. Kadar Pi pada IP $100 \%$ meningkat dengan menurunnya C-org. Penurunan C-org dan peningkatan DHL pada IP $200 \%$ diikuti oleh peningkatan Po. Penurunan Eh dan Feterlarut serta peningkatan C-org pada IP 300\% meningkatkan Pi. Penurunan dosis $\mathrm{P}_{2} \mathrm{O}_{5}$ dan peningkatan dosis jerami menurunkan Eh. Faktor yang paling berpengaruh terhadap produksi padi sawah adalah KAL.

\section{UCAPAN TERIMA KASIH}

Disampaikan terima kasih kepada G. Saputra, S. Yaenah, M. Afiton dan C.T. Hasibuan atas bantuannya dalam pengamatan lapang dan analisis laboratorium.

\section{DAFTAR PUSTAKA}

Bünemann, E.K., A. Oberson, F. Liebisch, F. Keller, K.E. Annaheim, O. Huguenin-Elle and F. Frossard. 2012. Rapid microbial phosphorus immobilization dominates gross phosphorus fluxes in a grassland soil with low inorganic phosphorus availability. Soil Biol. Biochem., 51: 84-95.

Chaudhari, P.R. and D.V. Abire. 2013. Electrical conductivity and dielectric constant as indication of available total macro and micro nutrients in the soil. Intern. J. Physics. Math. Sci., 3: 13-17.

Chong, Y.Q., L.Z. Yang, Z.H. Cao and S.H. Yin. 2009. Chronosequential changes of selected pedogenic properties in paddy soils as compared with nonpaddy soils. Geoderma, 151: 31-41.

Cyio, M.B. 2008. Efektifitas bahan organik dan tinggi genangan terhadap perubahan $\mathrm{Eh}, \mathrm{pH}$ dan status Fe, $\mathrm{P}$, dan Al terlarut pada tanah Ultisol. Agroland., 15: 257-269.

Duane, T., S. Gardiner and S. James. 2012. Wet soil redox chemistry as affected by organic matter and nitrate. Am. J. Clim. Change., 1: 205-209.

Ethan, S. 2015. Effect of flooding on chemistry of paddy soils. J. Inovat. Sci. Eng. Techno., 2: 413-420. 
Fan, M.S., R.F. Liang, E.S. Zhang, S.H. Lu and X.J. Liu. 2008. Nutrient management strategy of paddy riceupland crop rotation system. Chinese J. Appl. Ecol., 19: 421-432.

Gaol, M.D.L., M.S. Supriadi dan M. Sambiring. 2013. Survey dan pemetaan status fosfat lahan sawah pada daerah irigasi Bahal Gajah/Tiga Bolon, Kecamatan Sidamanik Kabupaten Simalungun. Agroekoteknologi, 1: 1226-1234.

Gupta, R.K., J.K. Ladha, J. Singh, G. Singh and H. Pathak. 2007. Yield and phosphorus transformation in a ricewheat system with crop residue and phosphorus management. Soil. Sci. Am. J., 7: 1500-1507.

Hartono, A., S. Funakawa and T. Kosaki. 2006. Transformation of added phosphorus to acid upland soil with different soil properties in Indonesia. Soil Sci. Plant. Nutr., 52: 734-744.

Idris, O.A.A. and S. Ahmed. 2012. Phosphorus sorption capacity as a guide for phosphorus availibility of selected Sudanese soil series. African. Crop Sci., 20: $59-65$.

Iranpour, M., A. Lakzian and R. Korrasami. 2014. Effect of cadmium and organic matter on soil $\mathrm{pH}$, electrical conductivity and their roles in cadmium availibility in soil. JMEAST, 18: 643-646.
Nayak, P., D. Patel, B. Ramakrishnan, A.K. Mishra and R.N. Samantaray. 2009. Long-term aplication effects of chemical fertilizer and compost on soil organic carbon under intensive rice-rice cultivation. Nutr. Cycl. Agroecosyst., 83: 259-269.

Pampolino, M.F., E.V. Laureles, H.C. Gines and R.J. Buresh. 2008. Soil carbon and nitrogen changes in long-term continuous lowland rice cropping. Soil Sci. Soc. Am. J., 2: 798-807.

Ponnamperuma, F.N. 1978. The chemistry of submerged soils and the growth of rice, p. 421-441 In Soil and Rice. International Rice Research Institute. Los Banos.

Ponnamperuma, F.N. 1985. Chemical kinetics of wetland rice soil relative to soil fertility, p. 71-89 In Wetland Soils: Characterization, Classification and Utilization. International Rice Research Institute. Los Banos.

Sahrawat, K.L. 2012. Soil fertility in flooded and nonflooded irrigated rice system. Ach. Agron. Soil Sci,. 58: 423-436.

Tiessen, H. and J.O. Moir. 2008. Characterization of available $\mathrm{P}$ by sequential extraction, p. 293-306 In: M.R. Carter and E.G. Gregorich (Eds.). Soil Sampling and Methods of Analysis. CRC Press, Boca Raton. 